\title{
GAMBARAN KUALITAS AIR BERSIH KAWASAN DOMESTIK DI JAWA TIMUR PADA TAHUN 2019
}

\section{DESCRIPTION OF QUALITY OF CLEAN WATER IN DOMESTIC AREA IN EAST JAVA IN 2019}

\author{
Rica Naudita Krisna Setioningrum ${ }^{1}$,_Lilis Sulistyorini ${ }^{2}$, Wahyu Istining Rahayu ${ }^{3}$ \\ ${ }^{1}$ Jurusan S1 Kesehatan Masyarakat, Fakultas Kesehatan Masyarakat, Universitas Airlangga, Kampus \\ C Mulyorejo 60115, Kecamatan Mulyorejo Kota Surabaya, Jawa Timur, Indonesia \\ ${ }^{2}$ Fakultas Kesehatan Masyarakat,Universitas Airlangga,Kampus C Mulyorejo 60115, Kecamatan \\ Mulyorejo Kota Surabaya, Jawa Timur, Indonesia \\ ${ }^{3}$ Balai Besar Teknik Kesehatan Lingkungan dan Pengendalian Penyakit, Jl Sidoluhur No.12, Indrapura \\ 60175 Kota Surabaya, Jawa Timur, Indonesia \\ Email: rica.naudita.krisna-2016@fkm.unair.ac.id
}

\begin{abstract}
East Java is a province that has many industrial centers and a population growth rate of $0.64 \%$. Along with population growth, the need for clean water will also increase. Problems that are often encountered in the community are related to water supply services in terms of water quality and quantity. Therefore, efforts to meet the quality of clean and healthy water need to be monitored regularly. The research objective was to describe the water quality physics (temperature, odor, total dissolved solids (TDS), turbidity, taste, color, and DHL), chemistry ( $\mathrm{pH}$, fluoride, chromium, lead, zinc, hardness, chloride, nitrate, nitrite, sulfate, organic substances, and detergent), and microbiology (total coliform) of domestic areas in East Java in 2019. The research method was quantitative descriptive with the Secondary Data Analysis approach, secondary data obtained from BBTKLPP Surabaya in JulyDecember 2019, there are 54 physical and chemical quality inspection samples, 29 microbiological quality inspection samples. The results of the clean water quality category that did not meet the requirements were physical quality (5.56\%) out of 54 samples, chemical quality (9.26\%) from 54 samples, and (27.58\%) out of 29 samples. The parameters of clean water quality in the domestic area do not meet the requirements, namely physical parameters (odor, TDS and taste), chemical parameters (manganese, hardness, chloride) microbiological parameters (total coliform). Suggestions are the need for routine inspections in an effort to maintain water quality and further research in the correct water treatment so as to obtain water that meets the clean water quality standard.
\end{abstract}

Keywords: Water quality, domestic water area, East Java

\begin{abstract}
Abstrak
Jawa Timur merupakan provinsi yang memiliki banyak pusat perindustrian dan laju pertumbuhan penduduk $0.64 \%$. Seiring dengan pertumbuhan penduduk maka kebutuhan air bersih juga akan meningkat. Permasalahan yang sering dijumpai di masyarakat berkaitan dengan pelayanan penyediaan air dari segi kualitas dan kuantitas air. Maka dari itu upaya pemenuhan air bersih yang berkualitas dan sehat perlu dilakukan pengawasan air bersih secara rutin. Tujuan penelitian adalah menggambarkan kualitas air secara fisik (suhu, bau, jumlah zat padat terlarut (TDS), kekeruhan, rasa, warna, dan DHL), kimia ( $\mathrm{pH}$, fluorida, kromium, timbal, seng, kesadahan, khlorida, nitrat,nitrit, sulfat, zat organik, dan deterjen), dan mikrobiologi (total koliform) pada kawasan domestik di Jawa Timur, tahun 2019. Metode penelitian adalah deskriptif kuantitatif dengan pendekatan Analisis Data Sekunder yang diperoleh dari BBTKLPP Surabaya pada Bulan Juli-Desember tahun 2019. Sampel yang digunakan sebanyak 54 sampel pemeriksaan kualitas fisik dan kimia, serta 29 sampel pemeriksaan kualitas mikrobiologi. Hasil penelitian kualitas air bersih kategori tidak memenuhi syarat adalah kualitas fisik $(5,56 \%)$ dari 54 sampel, kualitas kimia sebanyak $(9,26 \%)$ dari 54 sampel, dan $(27,58 \%)$ dari 29 sampel. Parameter kualitas air bersih di kawasan domestik kategori tidak memenuhi syarat yaitu parameter fisika (bau, TDS dan rasa), parameter kimia (mangan, kesadahan, khlorida) parameter mikrobiologik (total koliform). Saran perlu adanya pemeriksaan rutin sebagai upaya mempertahankan kulitas air dan
\end{abstract}


dilakukan penelitian lanjut dalam pengolahan air yang benar sehingga memperoleh air yang sesuai baku mutu air bersih.

Kata kunci: Kualitas air, air kawasan domestik, Jawa Timur

\section{PENDAHULUAN}

Air merupakan salah satu kebutuhan vital bagi kehidupan. Air bersih yang banyak digunakan di Indonesia berasal dari air tanah. Sumber air minum rumah tangga di Indonesia menggunakan air kemasan, air isi ulang, air ledeng dari PDAM maupun membeli eceran, sumur bor, sumur gali terlindung, mata air, penampungan air hujan, dan air sungai/irigasi. Hasil data dari Riset Kesehatan Dasar tahun 2013 jenis sumber air bersih untuk seluruh kebutuhan rumah tangga dan air minum di Indonesia pada umumnya adalah sumur gali terlindung $(29,9 \%)$, sumur pompa $(24,1 \%)$, PDAM (19,7\%), dan mata air (27\%). Di perkotaan, lebih banyak rumah tangga yang menggunakan air dari sumur bor/pompa $(32,9 \%)$ dan air ledeng/PDAM $(28,6 \%)$, sedangkan di pedesaan lebih banyak yang menggunakan sumur gali terlindung (32,7\%) (Riskesdas, 2013).

Tubuh manusia sekitar 50-60\% terdiri dari air sehingga konsumsi air yang dianjurkan per harinya kurang lebih 1,5 liter atau setara dengan 8 gelas. Sedangkan air bersih untuk keperluan sehari-hari per orang, rata-rata penggunaan air sekitar 30-60 liter (Briawan dkk., 2011dan Notoatmodjo, 2011). Kuantitas pemakaian air berhubungan erat dengan tingkat risiko mengalami gangguan kesehatan. Semakin rendah pemakaian air, semakin tinggi risiko terjadinya gangguan kesehatan (WHO, 2003).

Secara geografis wilayah Indonesia sebagian besar terdiri dari air. Namun faktanya, air yang dapat digunakan untuk kegiatan seharihari masih dalam kategori cukup dalam segi kualitas dan masih banyak dijumpai wilayah Indonesia yang mengalami krisis air bersih. Penyediaan air untuk memenuhi kebutuhan masyarakat merupakan salah satu agenda penting dalam menjamin kebutuhan dasar masyarakat. Target dan sasaran tersebut di Indonesia telah ditetapkan dalam Rencana Pembangunan Jangka Menengah Nasional (RPJMN) pada tahun 2015-2019, melalui peningkatan akses terhadap layanan air minum layak pada tahun 2019 menjadi 100\% (Sekretariat Kabinet RI, 2017). Hal tersebut menjelaskan bahwa kebutuhan penduduk terhadap air bersih yang layak adalah kebutuhan yang sangat krusial (Alihar, 2018).

Hasil survey tentang water acid tahun 2016 diperoleh hasil bahwa Indonesia menduduki peringkat ke-enam dalam daftar negara yang memiliki penduduk terbanyak dan mengalami kesulitan akses mendapatkan air bersih. Capaian akses air bersih di Indonesia mencapai angka $(72,55 \%)$ (BPS, 20018). Namun angka tersebut belum mencapai target RPJMN 2019 di Indonesia yaitu $100 \%$ akses air bersih yang layak.

Jawa Timur merupakan provinsi yang memiliki banyak pusat perindustrian dan laju pertumbuhan penduduk yang cukup tinggi yaitu 0.64\% (BPS,2019). Ketersediaan air berkaitan erat dengan dinamika pertambahan jumlah penduduk disuatu wilayah. Hal tersebut tentunya dapat berimplikasi terhadap akses untuk memperoleh air bersih, demikian juga di Provinsi Jawa Timur (Hunter, 2001).

Selain kesulitan akses mendapatkan air bersih, permasalahan yang sering dijumpai pada penyedian air bersih yaitu kualitas air yang digunakan masyarakat kurang memenuhi syarat sebagai air bersih dan sehat. Air bersih yang layak digunakan yaitu air yang memenuhi kualitas fisik, kimia, dan mikrobiologi. Persyaratan air bersih telah diatur dalam Peraturan Menteri Kesehatan RI nomor 416 tahun 1990 tentang Syarat-Syarat Dan Pengawasan Kualitas Air yang diperbarui dengan peraturan terbaru yaitu Peraturan Menteri Kesehatan RI nomor 32 tahun 2017 tentang Standar Baku Mutu Kesehatan Lingkungan dan Persyaratan Kesehatan Air Untuk Keperluan Higiene Sanitasi, Kolam Renang, Solus Per Aqua, Dan Pemandian Umum yang menjelaskan secara terperinci mengenai air berdasarkan peruntukannya.Baku mutu pada air bersih tersebut dipergunakan sebagai acuan batas kadar unsur yang terkandung di dalam air bersih sehingga dapat ditetapkan air tersebut memenuhi syarat sebagai air bersih dan layak digunakan oleh masyarakat. Maka dari itu upaya pemenuhan air bersih yang berkualitas dan sehat perlu dilakukan pengawasan air bersih secara rutin yang betujuan untuk mencegah penurunan kualitas dan penggunaan air yang dapat mengganggu atau membahayakan kesehatan. 
Oleh karena itu tujuan penelitian ini adalah untuk menggambarkan kualitas air secara fisik, kimia, dan mikrobiologi pada kawasan domestik di Jawa Timur, tahun 2019.

\section{METODE PENELITIAN}

Penelitian ini menggunakan metode penelitian deskriptif kuantitatif dengan pendekatan Analisis Data Sekunder (ADS). ADS merupakan suatu metode yang menggunakan data sekunder sebagai sumber data utama (Sugiyono, 2012). Data sekunder yang digunakan berasal dari hasil pemeriksaan air bersih di laboratorium BBTKLPP Surabaya yang telah terakreditasi oleh Komite Akreditasi Nasional (KAN) berupa pemeriksaan uji kualitas fisik, kimia, dan mikrobiologi air bersih yang mengacu pada baku mutu yang ada di Peraturan Menteri Kesehatan RI nomor 416 tahun 1990 tentang Syarat-Syarat Dan Pengawasan Kualitas Air. Hasil pemeriksaan air bersih mengacu pada peraturan lama dikarenakan alat uji di laboratorium BBTKLPP yang terakreditasi KAN masih menggunakan acuan peraturan lama.

Parameter fisik yang diuji antara lain suhu, bau, jumlah zat padat terlarut (TDS), kekeruhan, rasa, warna, DHL. Parameter kimia yang diuji antara lain $\mathrm{pH}$, fluorida, kromium, timbal, seng, kesadahan, khlorida, nitrat, nitrit, sulfat, zat organik, dan deterjen. Parameter mikrobiologi yang di uji antara lain total koliform. Data tersebut sudah melalui proses pengodingan pada sampel yang diujikan pada periode Bulan JuliDesember tahun 2019. Pemeriksaan parameter fisik dan kimia sebanyak 54 sampel dan pemeriksaan parameter mikrobiologi sebanyak 29 sampel dari wilayah Kabupaten/Kota di Provinsi Jawa Timur.

Hasil analisis kuantitatif tertulis dalam tabel berupa kualitas air bersih yang Memenuhi Syarat (MS) dan Tidak Memenuhi Syarat (TMS). Kategori MS untuk pemeriksaan kualitas fisik, kimia, dan mikrobiologi ditetapkan jika semua parameter yang diperiksa memenuhi baku mutu air bersih. Kategori TMS untuk kualitas fisik dan kimia jika terdapat $\geq 1$ parameter yang diperiksa tidak memenuhi baku mutu air bersih. Pemeriksaan kualitas mikrobiologi termasuk dalam kategori TMS jika parameter total koliform tidak memenuhi syarat baku mutu air bersih. Kemudian hasil tersebut dideskripsikan untuk memperoleh informasi terkait kualitas air bersih kawasan domestik di Jawa Timur pada tahun 2019.

\section{HASIL DAN PEMBAHASAN}

Kualitas Air Bersih Parameter Fisik (Suhu, Bau, Jumlah Zat Padat Terlarut (TDS), Kekeruhan, Rasa, Warna, dan DHL) Kawasan Domestik di Jawa Timur tahun 2019

Pada periode Juli - Desember 2019 terdapat 54 sampel air bersih kawasan pemukiman (domestik) yang berasal dari 11 Kabupaten/Kota di Jawa Timur yang diuji menggunakan parameter fisik. Hasil uji laboratorium menunjukkan bahwa terdapat tiga parameter fisika yang tidak memenuhi syarat yaitu bau, TDS dan rasa yang disajikan dalan Tabel 1.

Tabel 1. Hasil Uji Parameter Fisik Air Bersih Kawasan Domestik (Tidak Memenuhi Syarat) di Jawa Timur Periode Juli -Desember Tahun 2019

\begin{tabular}{|c|c|c|c|c|c|c|c|c|c|c|c|c|}
\hline \multirow{3}{*}{$\begin{array}{l}\text { Kabupaten/ } \\
\text { Kota }\end{array}$} & \multicolumn{4}{|c|}{ Parameter Bau } & \multicolumn{4}{|c|}{ Parameter TDS } & \multicolumn{4}{|c|}{ Parameter Rasa } \\
\hline & \multicolumn{2}{|c|}{ MS } & \multicolumn{2}{|c|}{ TMS } & \multicolumn{2}{|c|}{ MS } & \multicolumn{2}{|c|}{ TMS } & \multicolumn{2}{|c|}{ MS } & \multicolumn{2}{|c|}{ TMS } \\
\hline & $\mathbf{n}$ & $\%$ & $\mathbf{n}$ & $\%$ & $\mathbf{n}$ & $\%$ & $\mathbf{n}$ & $\%$ & $\mathbf{n}$ & $\%$ & $\mathbf{n}$ & $\%$ \\
\hline Bangkalan & 1 & 100,00 & 0 & 0,00 & 1 & 100,00 & 0 & 0,00 & 1 & 100,00 & 0 & 0,00 \\
\hline Banyuwangi & 1 & 100,00 & 0 & 0,00 & 1 & 100,00 & 0 & 0,00 & 1 & 100,00 & 0 & 0,00 \\
\hline Gresik & 1 & 50,00 & 1 & 50,00 & 2 & 100,00 & 0 & 0,00 & 2 & 100,00 & 0 & 0,00 \\
\hline Malang & 9 & 100,00 & 0 & 0,00 & 9 & 100,00 & 0 & 0,00 & 9 & 100,00 & 0 & 0,00 \\
\hline Situbondo & 2 & 100,00 & 0 & 0,00 & 2 & 100,00 & 0 & 0,00 & 2 & 100,00 & 0 & 0,00 \\
\hline Pasuruan & 2 & 100,00 & 0 & 0,00 & 2 & 100,00 & 0 & 0,00 & 2 & 100,00 & 0 & 0,00 \\
\hline Probolinggo & 5 & 100,00 & 0 & 0,00 & 5 & 100,00 & 0 & 0,00 & 5 & 100,00 & 0 & 0,00 \\
\hline Sampang & 10 & 100,00 & 0 & 0,00 & 10 & 100,00 & 0 & 0,00 & 10 & 100,00 & 0 & 0,00 \\
\hline Sumenep & 5 & 100,00 & 0 & 0,00 & 5 & 100,00 & 0 & 0,00 & 5 & 100,00 & 0 & 0,00 \\
\hline Surabaya & 8 & 100,00 & 0 & 0,00 & 6 & 75,00 & 2 & 25,00 & 6 & 75,00 & 2 & 25,00 \\
\hline Tulungagung & 9 & 100,00 & 0 & 0,00 & 9 & 100,00 & 0 & 0,00 & 9 & 100,00 & 0 & 0,00 \\
\hline
\end{tabular}

Sumber: BBTKLPP Surabaya tahun 2019

Parameter pertama tentang baku mutu parameter bau pada Permenkes RI No 416 tahun
1990 Tentang Syarat- Syarat Dan Pengawasan Kualitas Air, yaitu tidak berbau. Data hasil uji 
menunjukkan bahwa 1,85\% sampel air bersih kawasan domestik di Jawa Timur tidak memenuhi syarat parameter bau. Sampel air bersih yang tidak memenuhi syarat baku mutu parameter bau berasal dari kawasan domestik yang ada di Kabupaten Gresik.

Kabupaten Gresik sejak dulu menjadi salah satu wilayah di Jawa Timur yang menjadi kawasan industri. Selain berdampak positif pada perekonomian masyarakat, di sisi lain akan menimbulkan pencemaran lingkungan. Hal ini sering kali terjadi di Kabupaten Gresik adalah penurunan kualitas air sumur akibat pencemaran tanah di sekeliling kawasan industri (Sholikhah dkk.,2017). Bau dapat timbul karena adanya kontaminasi dalam air baik yang bersifat alami maupun antropogenik. Sumber kontaminasi yang bersifat alami misalnya hasil metabolisme dari algae dan mikroorganisme heterophik (Actinomycetes) dalam badan air atau di dalam tanah. Kontaminasi juga dapat berasal dari sumber domestik seperti aktivitas manusia buang air besar di sembarang tempat sehingga dapat menimbulkan bau pada air karena sumber kontaminan masuk kedalam sumur melalui resapan air didalam tanah (Naibaho, 2007).

Beberapa jenis bau pada air memiliki faktor risiko dan penyebabnya. Bau minyak bumi, bahan bakar, atau pelarut kemungkinan disebabkan oleh kebocoran tangki penyimpanan di dalam tanah. Bau klorin, bahan kimia, dan obat kemungkinan adanya penambahan klorin atau penumpukan bahan tersebut di dalam saluran pipa air. Hal tersebut dalam jangka panjang akan berdampak pada kesehatan manusia (Sutrisno,2006). Efek bau pada air bersih yaitu dapat menggangu kenyamanan bagi orang tertentu yang memiliki sensifitas tinggi terhadap bau. Pengaruh bau klorin terhadap kesehatan, terutama senyawa organoklorin seperti PCBs, Dioksin, DDT dan lain-lain adalah dapat mengganggu sistem kekebalan tubuh, merusak hati dan ginjal, gangguan pencernaan, gangguan pada sistem saraf (neurological), dapat menyebabkan kanker dan gangguan sistem reproduksi yang dapat menyebabkan keguguran (Hasan A, 2006).

Parameter kedua tenang baku mutu TDS pada air bersih yaitu $1500 \mathrm{mg} / \mathrm{l}$. Data hasil uji

Kualitas Air Bersih Parameter Kimia (pH,
Fluorida, Kromium, Timbal, Seng,
Kesadahan, Khlorida, Nitrat, Nitrit, Sulfat,
(Tabel 1) menunjukkan bahwa 3,70\% sampel air bersih kawasan domestik di Jawa Timur tidak memenuhi syarat parameter TDS. Sampel air bersih yang tidak memenuhi syarat parameter TDS berasal dari kawasan domestik di Kota Surabaya dengan nilai sebesar $24.980 \mathrm{mg} / \mathrm{l}$ dan $12.180 \mathrm{mg} / \mathrm{l}$. Hal ini disebabkan di Surabaya banyak sungai menerima limbah yang berasal dari berbagai buangan limbah rumah tangga dan industri (Sholikhah, 2017). Angka TDS yang tinggi dipengaruhi oleh tingginya kandungan zat padat yang terlarut dalam air. Konsentrasi TDS dari sumber alami ditemukan bervariasi mulai $<30 \mathrm{mg} / \mathrm{l}$ sampai >600 mg/l (WHO, 2003). Potensi sumber pencemar TDS dalam air bersih berkaitan dengan tingginya kandungan mineral dalam tanah yang dapat mempengaruhi air tanah yang digunakan sebagai air baku.

Air yang mengandung TDS tinggi tidak baik untuk kesehatan manusia. Mineral yang terkandung didalam air tidak hilang dengan cara direbus. Bila terlalu banyak mineral anorganik di dalam tubuh dalam jangka waktu panjang akan mengendap di dalam tubuh dan berakibat tersumbatnya berbagai saluran di dalam tubuh seperti batu empedu atau batu ginjal (Sasongko dkk.,2014). Apabila air bersih digunakan sebagai bahan baku air minum, maka angka TDS harus memenuhi persyaratan air minum.

Parameter ketiga tentang baku mutu rasa pada air bersih yaitu tidak berasa. Data hasil uji menunjukkan bahwa 3,70\% sampel air bersih kawasan domestik di Jawa Timur tidak memenuhi syarat parameter rasa. Sampel air bersih yang tidak memenuhi syarat parameter rasa berasal dari kawasan domestik wilayah Surabaya.

Menurut Washington Taste Departement of Health (2018) air bersih yang tidak memenuhi persyaratan parameter rasa memiliki beberapa penyebab antara lain rasa logam disebabkan bahan logam (besi,tembaga dan mangan) larut ke dalam air melalui pipa. Rasa klorin, bahan kimia dan obat kemungkinan ada penambahan klorin di pengolahan untuk proses disenfektan. Salte taste biasanya kadar natrium, magnesium, dan kalium yang tinggi di dalam air secara alami akan menyebabkan rasa asin. Risiko ini terjadi jika sumber air ini terletak di dekat pantai.

\section{Zat Organik, Dan Deterjen) Kawasan Domestik di Jawa Timur Tahun 2019}

Pada periode Juli - Desember 2019 terdapat 54 sampel air bersih domestik dari 11 Kabupaten/Kota wilayah Jawa Timur yang diuji menggunakan parameter kimia. Hasil uji 
menunjukkan bahwa terdapat tiga parameter kimia yang tidak memenuhi syarat yaitu mangan, kesadahan, dan khlorida (Tabel 2). Parameter pertama tentang baku mutu mangan pada air bersih yaitu $0,5 \mathrm{mg} / \mathrm{l}$. Data hasil uji menunjukkan bahwa 9,26\% sampel air bersih kawasan domestik di Jawa Timur tidak memenuhi syarat parameter mangan. Sampel air bersih uji parameter mangan yang tidak memenuhi syarat berasal dari kawasan domestik di Kabupaten Tulungagung dan Kota Surabaya dengan nilai konsentrasi mangan sebesar 5,316 $\mathrm{mg} / \mathrm{l}$.

Tabel 2. Hasil Uji Parameter Kimia Air Bersih Kawasan Domestik (Tidak Memenuhi Syarat) di Jawa Timur Periode Juli -Desember tahun 2019

\begin{tabular}{|c|c|c|c|c|c|c|c|c|c|c|c|c|}
\hline \multirow{3}{*}{$\begin{array}{l}\text { Kabupaten/ } \\
\text { Kota }\end{array}$} & \multicolumn{4}{|c|}{ Parameter Mangan } & \multicolumn{4}{|c|}{ Parameter Kesadahan } & \multicolumn{4}{|c|}{ Parameter Khlorida } \\
\hline & \multicolumn{2}{|c|}{ MS } & \multicolumn{2}{|c|}{ TMS } & \multicolumn{2}{|c|}{ MS } & \multicolumn{2}{|c|}{ TMS } & \multicolumn{2}{|c|}{ MS } & \multicolumn{2}{|c|}{ TMS } \\
\hline & $\mathbf{n}$ & $\%$ & $\mathbf{n}$ & $\%$ & $\mathbf{n}$ & $\%$ & $\mathbf{n}$ & $\%$ & $\mathbf{n}$ & $\%$ & $\mathbf{n}$ & $\%$ \\
\hline Bangkalan & 1 & 100,00 & 0 & 0,00 & 1 & 100,00 & 0 & 0 & 1 & 100,00 & 0 & 0 \\
\hline Banyuwangi & 1 & 100,00 & 0 & 0,00 & 1 & 100,00 & 0 & 0 & 1 & 100,00 & 0 & 0 \\
\hline Gresik & 2 & 100,00 & 0 & 0,00 & 2 & 100,00 & 0 & 0 & 2 & 100,00 & 0 & 0 \\
\hline Malang & 9 & 100,00 & 0 & 0,00 & 9 & 100,00 & 0 & 0 & 9 & 100,00 & 0 & 0 \\
\hline Situbondo & 2 & 100,00 & 0 & 0,00 & 2 & 100,00 & 0 & 0 & 2 & 100,00 & 0 & 0 \\
\hline Pasuruan & 2 & 100,00 & 0 & 0,00 & 2 & 100,00 & 0 & 0 & 2 & 100,00 & 0 & 0 \\
\hline Probolinggo & 5 & 100,00 & 0 & 0,00 & 5 & 100,00 & 0 & 0 & 5 & 100,00 & 0 & 0 \\
\hline Sampang & 10 & 100,00 & 0 & 0,00 & 10 & 100,00 & 0 & 0 & 10 & 100,00 & 0 & 0 \\
\hline Sumenep & 5 & 100,00 & 0 & 0,00 & 5 & 100,00 & 0 & 0 & 5 & 100,00 & 0 & 0 \\
\hline Surabaya & 5 & 62,50 & 3 & 37,50 & 6 & 75,00 & 2 & 25 & 6 & 75,00 & 2 & 25 \\
\hline Tulungagung & 7 & 77,78 & 2 & 22,22 & 9 & 100,00 & 0 & 0 & 9 & 100,00 & 0 & 0 \\
\hline
\end{tabular}

Sumber: BBTKLPP Surabaya tahun 2019

Mangan dapat larut dalam air dan juga berikatan dengan unsur lain didalam air khlorida, sulfat dan nitrat (Effendi, 2003). Mangan merupakan logam yang terbentuk secara alami pada material padat seperti tanah, bebatuan, dan mineral. Pada lapisan akuifer terjadi kontak antara air tanah dengan material padat tersebut sehingga komponennya termasuk mangan ikut terlarut ke dalam air. Pada saat konsentrasi mangan mencapai $0,05 \mathrm{mg} / \mathrm{l}$ dampak yang timbul biasanya berupa perubahan pada air yaitu rasa, warna (coklat, ungu, atau hitam) dan kekeruhan (Fauziah, 2010). Namun risiko kesehatan yang ditimbulkan tidak signifikan. Adapun yang berpendapat lain bahwa mangan memiliki beberapa risiko kesehatan dalam jangka waktu pendek. Mangan dapat menimbulkan gangguan sistem pernapasan seperti lemas, batuk, sesak napas, bronchopneumonia, edema paru, dan cyanosis serta methemoglobinemia. Dampak penyimpangan parameter zat kimia mangan adalah dapat meningkatkan reaktivitas pada pembuluh tenggorokan dan sensitivitas pada penderita asma. Zat kimia bersifat racun terutama terhadap paru dengan diawali gangguan pada pernafasan (Sunarsih, 2018).

Parameter kedua tentang baku mutu kesadahan pada air bersih yaitu $500 \mathrm{mg} / \mathrm{l}$. Data hasil uji pada Tabel 2 menunjukkan bahwa $3,70 \%$ sampel air bersih kawasan domestik di
Jawa Timur tidak memenuhi syarat parameter kesadahan. Sampel air bersih yang tidak memenuhi syarat parameter kesadahan berasal dari kawasan domestik di Kota Surabaya dengan kadar kesadahan tertinggi sebesar 9.271,5mg/l.

Pada air rumah tangga, tingkat kesadahan yang tinggi mengakibatkan kinerja sabun yang lebih banyak. Kesadahan juga dapat menimbulkan kerak pada dinding peralatan dapur sehingga berakibat pada kerusakan peralatan dapur. Masalah kesadahan air seringkali ditemukan pada daerah yang tanahnya mengandung kapur. Kesadahan disebabkan adanya ion $\mathrm{Ca}$ dan $\mathrm{Mg}$ secara bersama (Said, 2005; Astuti dkk., 2016). Sejumlah besar penelitian berusaha menyelidiki efek kesehatan yang ditimbulkan oleh kesadahan. Namun, kesadahan tidak mempengaruhi kalsium urin dan sedimentasi kalsium oksalat, dan juga tidak ada hubungan antara kalsium, magnesium, atau kesadahan total dengan penyakit jantung iskemik atau kematian akibat stroke. (Izhar dkk.,2007; Leurs dkk., 2010).

Parameter ketiga yaitu tentang baku mutu khlorida pada air bersih yaitu $600 \mathrm{mg} / \mathrm{l}$. Data hasil uji pada Tabel 2 menunjukkan bahwa 3,70\% sampel air bersih kawasan domestik di Jawa Timur tidak memenuhi syarat parameter khlorida. Sampel air bersih uji parameter khlorida yang tidak memenuhi syarat berasal 
dari kawasan domestik di Kota Surabaya dengan nilai $15.698,338 \mathrm{mg} / \mathrm{l}$.

Keberadaan khlorida terdistribusi secara luas di alam sebagai garam natrium $(\mathrm{NaCl})$, kalium $(\mathrm{KCl})$, dan kalsium $\left(\mathrm{CaCl}_{2}\right)$. Khlorida pada air permukaan dan air tanah dapat bersumber dari sumber alami maupun antropogenik. Sumber alami biasanya berasal dari bebatuan yang terlarut dalam tanah dan air. Sumber antropogenik bersumber dari limpasan yang mengandung garam. Peningkatan konsentrasi khlorida dalam air dapat terjadi karena adanya proses pengolahan yang melibatkan klorida (WHO, 2011). Kelebihan ion klorida masuk kedalam tubuh menjadi faktor risiko terjadinya kerusakan organ ginjal. Namun jika tubuh kekurangan ion klorida dapat menurunkan tekanan osmotik cairan ekstraseluler yang menyebabkan peningkatan suhu tubuh (Ngibad dkk., 2019).

\section{Kualitas Air Bersih Parameter Mikrobiologi (Total Koliform) Kawasan Domestik di Jawa Timur Tahun 2019}

Pada periode Juli-Desember 2019 terdapat 29 sampel air bersih kawasan domestik dari 10 Kabupaten/Kota di Jawa Timur yang diuji menggunakan parameter mikrobiologi. Hasil menunjukkan bahwa parameter total koliform tidak memenuhi syarat. Jumlah sampel uji mikrobiologi yaitu sebanyak 29 sampel yang berasal dari sumber air perpipan.

Baku mutu total koliform pada air bersih yaitu 10 per $100 \mathrm{ml}$ pada air bersih perpipaan. Data hasil uji menunjukkan bahwa air perpipaan kawasan domestik di Jawa Timur, sebanyak $27,58 \%$ tidak memenuhi syarat parameter mikrobiologi (total koliform). Sampel air bersih dari kawasan domestik yang tidak memenuhi syarat berasal dari 3 Kabupaten/Kota yang diuji. Hasil uji air bersih kawasan domestik di Jawa Timur menunjukkan kadar total koliform tertinggi sebesar >1600 per $100 \mathrm{ml}$ yang berasal dari Sumenep dan Surabaya.

Bakteri fecal yang sering dijumpai yaitu coliform yang berasal dari hewan atau tumbuhan yang sudah mati. Beberapa jenisnya antara lain bakteri Eschericia coli, Klebsiella, Enterobacter, dan Pseudomonas. Bakteri coliform sewajarnya terdapat pada kotoran manusia atau hewan. Keberadaan coliform pada air bersih menunjukkan adanya kontaminasi yang bersifat pathogen dan dapat menimbulkan penyakit seperti diare (Kusuma, dkk., 2015). Faktor risiko cemaran coliform berkaitan erat dengan higiene dan sanitasi. Pada kawasan domestik, total coliform harus diperhatikan karena penggunaan air bersih oleh kalangan yang luas. Letak sumur lebih tinggi dari sumber pencemaran seperti kakus, kandang ternak, tempat sampah dan berjarak minimal 15 meter (Chandra, 2007). Total coliform menjadi parameter bahwa air yang terkontaminasi bakteri tersebut dan melebihi baku mutu, dapat menimbulkan gangguan pencernaan dengan gejala seperti diare. Bakteri ini menjadi penyebab diare melalui fecal oral yaitu dari makanan atau minuman yang dikonsumsi dan tercemar oleh bakteri tersebut (Sekarwati, dkk., 2016).

Tabel 3. Hasil Uji Parameter Total Koliform Air Bersih Perpipaan Kawasan Domestik di Jawa Timur Periode Juli -Desember tahun 2019

\begin{tabular}{clcccc}
\hline \multirow{2}{*}{ No } & Kabupaten/K & \multicolumn{2}{c}{ MS } & \multicolumn{2}{c}{ TMS } \\
\cline { 3 - 6 } & \multicolumn{1}{c}{ ota } & n & n & \% \\
\hline 1 & Bangkalan & 0 & 0 & 4 & 100 \\
2 & Banyuwangi & 1 & 100 & 0 & 0 \\
3 & Gresik & 1 & 100 & 0 & 0 \\
4 & Bojonegoro & 2 & 100 & 0 & 0 \\
5 & Pasuruan & 1 & 100 & 0 & 0 \\
6 & Probolinggo & 3 & 100 & 0 & 0 \\
7 & Situbondo & 4 & 100 & 0 & 0 \\
8 & Sumenep & 1 & 33.33 & 2 & 66.67 \\
9 & Surabaya & 6 & 85.71 & 1 & 14.29 \\
10 & Sidoarjo & 2 & 66.67 & 1 & 33.33 \\
\hline
\end{tabular}

Sumber: BBTKLPP Surabaya tahun 2019

\section{KESIMPULAN DAN SARAN}

\section{Kesimpulan}

Kualitas air bersih kawasan domestik di Jawa Timur pada periode Juli-Desember 2019 masih terdapat yang Tidak Memenuhi Syarat (TMS) yaitu untuk pemeriksaan kualitas fisika $5,56 \%$, kualitas kimia sebanyak 9,26\%, dan kualitas mikrobiologik air bersih perpipaan sebanyak 27,58\% dari 29 sampel air bersih. Parameter kualitas air bersih di kawasan domestik yang tidak memenuhi syarat yaitu parameter fisika (bau, TDS dan rasa), parameter kimia (mangan, kesadahan, khlorida), dan parameter mikrobiologik (total koliform).

\section{Saran}

Perlu adanya upaya untuk mempertahankan kualitas air bersih yang sudah memenuhi syarat yaitu dengan cara pemeriksaan rutin kualitas air di laboratorium. Sedangkan untuk air bersih yang belum memenuhi syarat perlu adanya penelitian lanjut untuk melakukan pengolahan 
air yang benar sehingga menghasilkan kualitas air sesuai syarat baku mutu kualitas air yang layak digunakan untuk keperluan sehari hari.

\section{DAFTAR RUJUKAN}

1] Alihar,F.2018. Penduduk dan Akses Air Bersih di Kota Semarang. Jurnal Kependudukan Indonesia, 13(1), 67-76

2] Astuti,D., Fatimah., Anie. 2016. Analisis Kadar Kesadahan Total Pada Air Sumur Di Padukuhan Bandung Playen Gunung Kidul Yogyakarta. Jurnal Analytical and Environmental Chemistry,1(01), 69-73

3] Badan Penelitian dan Pengembangan Kesehatan Riset Kesehatan Dasar (RISKESDAS). 2013. Hasil Utama Riskesdas 2013. Kementerian Kesehatan Republik Indonesia

4] Badan Penelitian dan Pengembangan Kesehatan Riset Kesehatan Dasar (RISKESDAS).2018. Hasil Utama Riskesdas 2018. Kementerian Kesehatan RI

5] Briawan,D., Ekawati,I. 2011. Kebiasaan Minum dan Asupan Cairan Remaja di Perkotaan. Jurnal Gizi Klinik Indonesia, Vol.8:36-41

6] Chandra.2007. Pengantar Kesehatan Lingkungan. Penerbit Buku Kedokteran, Jakarta

7] Effendi,H.2003. Telaah Kualitas Air. Kanisius, Yogyakarta

8] Fauziah, A.2010. Efektivitas Saringan Pasir Cepat Dalam Menurunkan Kadar Mangan (Mn) Pada Air Sumur Dengan Penambahan Kalium Permanganat (KMnO4) 1\%. Skripsi : FKM USU Medan

9] Hunter, L. 2001. Population and Environment: A complex relationship in population matters. Research Brief.Santa Monica, California

10] Izhar, M., Haripurno. 2007. Hubungan Antara Kesadahan Air Minum, Kadar Kalsium dan Sedimen Kalsium Oksalat Urin Pada Anak Usia Sekolah Dasar. Jurnal Berita Kedokteran Masyarakat 23(4),200209

11] Kementerian Kesehatan Republik Indonesia. 1990. Peraturan Menteri Kesehatan Republik Indonesia Nomor
416/MENKES/PER/IX/1990 tentang Syarat-Syarat dan Pengawasan Kualitas Air,Jakarta

12] Kementerian Kesehatan Republik Indonesia. 2017. Peraturan Menteri Kesehatan Republik Indonesia Nomor 32 tahun 2017 tentang Standar Baku Mutu Kesehatan Lingkungan dan Persyaratan Kesehatan Air Untuk Keperluan Higiene Sanitasi, Kolam Renang, Solus Per Aqua, dan Pemandian Umum.

13] Kusuma E., Rasyid., Endri. 2015. Identifikasi Bakteri Coliform pada Air Kobokan di Rumah Makan Kelurahan Andalas Kecamatan Padang Timur. Jurnal Kesehatan Andalas, 4(3),845-849

14] Leurs, L.J et al. 2010. Relationship between tap water hardness, magnesium, and calcium concetration and mortality due to ischemic heart disease or stroke in the Netherlands. Environmental Health.220(4):736-743

15] Naibaho,B.2007. Analisis Kualitas Fisik dan Kimia di Daerah Medan Sekitarnya, Medan

16] Ngibad,K., Herawati. 2019. Analysis of Chloride Levels in Well and PDAM Water in Ngelom Village, Sidoarjo. Jurnal Kimia dan Pendidikan Kimia,4(01), 1-6,

17] Notoatmodjo, S., 2011. Kesehatan Masyarakat: Ilmu dan Seni. Kesehatan Masyarakat: Ilmu Dan Seni. Rineka Cipta,Jakarta

18] Said, Nusa.2005. Metode Penghilangan Zat Besi dan Mangan di dalam Penyediaan Air Minum Domestik.Jurnal JAI,1(3)

19] Sasongko, E., Widyastuti. 2014. Kajian Kualitas Air dan Penggunaan Sumur Gali Oleh Masyarakat di Sekitar Sungai Kaliasi Kabupaten Cilacap. Jurnal Ilmu Lingkungan, 12(2),72-82

20] Sekarwati, N., Wulandari. 2016. Analisis Kandungan Bakteri Total Coliform Dalam Air Bersih dan Escherecia Coli dalam Air Minum Pada Depot Air Minum Isi Ulang di Wilayah Kerja Puskesmas Kalasan Sleman. Kesmas,10(2), 1-12

21] Sekretariat Kabinet RI. 2017. Lampiran Peraturan Presiden Republik Indonesia Nomor 59 Tahun 2017 tentang Pelaksanaan Pencapaian Tujuan 
Pembangunan Berkelanjutan. [Online] http://setkab.go.id/category/peraturan.

22] Sholikhah, E, M., 2017. Pencemaran Lingkungan Di Kabupaten Gresik (19701994). Jurnal Kesejarahan, 11(2), 117 128.

23] Sugiyono. 2012. Metode Penelitian Kuantitatif, Kualitatif dan $R \& D$. Alfabeta, Bandung

24] Sunarsih,E, Fikry,A., Windusari., Trisaini,I., Arista,D., Septiawati,D., Ardila,Y., Purba,I., Garmini,R., 2018. Analisis Paparan Kadmium Besi dan Mangan pada Air Terhadap Gangguan Kulit
Pada Masyarakat Desa Ibul Besar Kecamatan Indralaya Selatan Kabupaten Ogan Ilir. Jurnal Kesehatan Lingkungan, 17(2), 63-73

25] Sutrisno,C.T. 2006. Teknologi Penyediaan Air Bersih. Cetakan ke enam. Rineka Cipta, Jakarta

26] WHO. 2003. Guidline for drinking-water quality, Health criteria and other supporting information. Geneva, WHO

27] WHO. 2011. Chloride in Drinking-water. WHO Guedline Drink-Water, WHO

28] WHO. 2003. Domestic water quantity, service level and health. WHO 